\title{
Kell-e készülnünk a földönkívüli civilizációkkal való találkozásra? ${ }^{2}$
}

\begin{abstract}
Tavaly volt 70 éve, hogy Enrico Fermi megfogalmazta híres paradoxonát: ha lennének földönkívüli civilizációk, már találkoznunk kellett volna velük. Az elmúlt évtizedekben számos kísérlet történt az ellentmondás feloldására, de annak tisztázására csak alig, hogy az egyes magyarázatokból milyen stratégia következik az emberiség számára - pedig egy ilyen esemény potenciálisan a teljes megsemmisülésünkkel járhat. Jelentenek-e fenyegetést a földönkivüliek? Mit tegyünk, hogy túléljük a velük való találkozást? Az ezekre a kérdésekre adott válasz nagyban függ attól, hogy milyen magyarázatokat tartunk valószínünek a Fermi által felvetett problémára. Ez a tanulmány nem vállalkozik arra, hogy kimerítően elemezze - vagy akár csak felsorolja - az elmúlt évtizedekben javasolt számtalan lehetséges választ, megelégszik azzal, hogy a legfontosabbakat négy nagy kategóriába rendezze, és erre építve megvizsgálja, hogy a különböző feltételezések milyen cselekvési irányt tesznek szükségessé az emberiség biztonságának megóvása érdekében.
\end{abstract}

Kulcsszavak: földönkívüli civilizáció, egzisztenciális fenyegetés, Fermi-paradoxon

\begin{abstract}
Should We Prepare for the Encounter with Extraterrestrial Civilisations?
It was 70 years ago last year that Enrico Fermi articulated his famous paradox: if there were extraterrestrial civilisations, we should have already met them. There have been many attempts in recent decades to resolve the contradiction, but hardly any to clarify the strategies which ensue for humanity from the individual explanations - even though such an event may result in our annihilation. Do extraterrestrials represent a threat? What should we do to survive our encounter? The answer to these questions depends largely on what explanations we consider likely for the problem raised by Fermi. The present study does not undertake to exhaustively analyse, or even list the myriad possible responses proposed in recent decades, it shall confine itself to sorting the most important into four broad categories and, on that basis, to examine the course of action required by the various assumptions in order to safeguard the security of mankind.
\end{abstract}

Keywords: extraterrestrial civilisation, existential threat, Fermi paradox

\section{Hol van mindenki?}

A Tejútrendszer sugara legalább 85 ezer fényév, ami azt jelenti, hogy egy a fénysebesség huszadával (ami nyolcvanszorosa a leggyorsabb ember által készített eszköz sebességének) haladó űrhajónak nagyjából három és fél millió évébe telne átszelni. Első látásra úgy tünik,

Dobos Gábor okleveles biztonság- és védelempolitikai szakértő.

A szerző köszönetet mond Almár Ivánnak a cikk kéziratához füzött megjegyzéseiért. 
hiába is alakulna ki a galaxisunk százmilliárd $\left(10^{11}\right)$ csillagja körül keringő bolygók bármelyikén intelligens élet, ilyen távolságok mellett nem csoda, hogy még nem találkoztunk vele. Azonban ennek éppen az ellenkezője az igaz: ha létrejött volna, már régen itt kellene lennie.

Ha egy technikai civilizáció nekiveselkedik a galaxis gyarmatosításának, kozmikus léptékben viszonylag gyorsan a végére ér. Számos indok hozható fel az elindulás mellett - amelyekre később még visszatérünk -, az azonban viszonylag egyértelmü, hogy ha egyszer megszületett az elhatározás, hogyan érdemes tenni. Neumann János az 1950-es évek elején dolgozta ki egy olyan univerzális összeszerelő gép gondolatát, amely képes önmagáról másolatot készíteni. ${ }^{3}$ Amikor megérkeznek egy alkalmas égitestre, ezek az önmásoló Neumann-szondák az ott található nyersanyagokból képesek lennének önmaguk tökéletes másolatát elöállítani (és az utazáshoz szükséges üzemanyagot kibányászni), hogy azután ezek a másolatok újabb naprendszerekbe indulhassanak tovább. ${ }^{4}$ Jó közelítéssel azt lehet mondani, hogy a szomszédos bolygórendszerek átlagos távolsága öt fényév. Ha feltételezzük, hogy a szonda átlagsebessége a fénysebesség huszada, ezt a távolságot kereken 100 év alatt teszi meg. Ha abból indulunk ki, hogy kell még 100 év, amíg megépíti másolatait, arra az eredményre jutunk, hogy 200 év szükséges egy öt fényév sugarú térrész kolonizálásához, vagyis a gyarmatosítás sebessége 0,025 fényév/év. ${ }^{5}$ A Tejútrendszer legtávolabbi pontja 110 ezer fényévnyire van a Naptól, így még ha az idegen civilizáció ebből a legtávolabbi pontból indul is, 4,4 millió év alatt eléri a naprendszert. (A szonda sebességének megadott 0,05-szoros fénysebesség, noha elvben már a jelenlegi fizikai ismereteink szerint sem elérhetetlen, némiképp véletlenszerü. De még ha a szondák sebessége csak tizede is ennek, és nem 100, hanem 500 év kell ahhoz, hogy legyártsák másolataikat, akkor sem tart tovább 33 millió évnél, mire elérik a galaxis legtávolabbi pontját.) Vegyük észre, hogy - a legelső lépésben indított szondákat leszámítva - a gyarmatosító civilizációnak ez nem kerül semmibe, mert a szondák kizárólag a helyben talált nyersanyagokat használják fel. Az exponenciális növekedés miatt ez a galaxis gyarmatosításának leggyorsabb és legolcsóbb módja ${ }^{6}$ - ha egy civilizációban megérett a döntés, hogy belevág, miért választana lassabb és drágább utat?

A Föld kora 4,46 milliárd év, miközben a Tejút Föld-típusú bolygóinak medián kora legalább 5,7 milliárd év (vagyis felük idősebb, felük fiatalabb ennél). ${ }^{7}$ Ha csak minden századik csillag körül kering Föld-típusú bolygó (ami konzervatív becslés), az akkor is félmilliárd a miénkhez hasonló, de annál legalább 1,24 milliárd évvel idősebb bolygót jelent. Ha ezek közül bármelyikről útjára indult volna a galaxist meghódító civilizáció, azt világosan látnunk kellene - de nem látunk semmit.

John von Neumann: Theory of Self-reproducing Automata. Urbana-London, University of Illinois Press, 1966.

Ez azt feltételezi, hogy ez a folyamat teljesen automatizálható, illetve hogy a szondák meghibásodás esetén képesek önmagukat kijavítani. Megjegyzendő, hogy bár a Neumann-szondák előállításának elméleti lehetősége általánosan elfogadott, a gyakorlatban (még) nem került sor ilyen eszköz megépítésére.

5 Frank J. Tipler: Extraterrestrial intelligent beings do not exist. Quarterly Journal of the Royal Astronomical Society, 21. (1980), 272.

6 Milan M. Ćirković: Fermi’s paradox: The last challenge for copernicanism? Serbian Astronomical Journal, (2009), 178. 4. Ćirković (2009) i. m. 2-3. 
Mielőtt rátérünk a lehetséges magyarázatokra, pontosítanunk kell, hogy mi az, amit nem látunk. Nyikolaj Kardasov 1964-ben javasolt egy skálát a technológiai civilizációk besorolására annak függvényében, hogy mennyi energia felett rendelkeznek: az I-es szinten planétájuk, a II-esen naprendszerük, a III-ason galaxisuk minden erőforrása felett. ${ }^{8}$ A Kardasov-skála egyik erőssége, hogy az eltelt közel 60 év dacára alig sikerült kitalálni olyan forgatókönyveket, amelyek megmagyaráznák, miért állna meg egy technikai civilizáció energiafelhasználásának növekedése fennállása során. ${ }^{9}$ A naprendszerben a legtöbb és legkönnyebben hozzáférhető energiát a Nap adja: tízmilliárd éves élettartama alatt - miközben tömege egy ezrelékét alakítja energiává - nagyjából $3 \times 10^{43}$ joule-t. Összehasonlításképpen, mivel együttes tömegük a Napénak ezrede, ugyanennyi energia szabadulna fel akkor, ha sikerülne az összes bolygót egy az egyben, tökéletesen veszteségmentesen energiává alakítani; minden más elképzelhető energiaforrás pedig legalább hétnyolc nagyságrenddel elmarad ettől. ${ }^{10} \mathrm{~A}$ bolygókkal szemben a Nap már most is egy müködő fúziós erőmü, kézenfekvő tehát a szétsugárzott energiáját összegyüjteni. Ez a központi csillag körül keringő hatalmas napelemekkel lenne lehetséges, amelyek - mivel kitakarnák annak látható fényét, de közben az infravörös tartományban sugároznának - hatalmas távolságokról észlelhetők lennének.

Akármerre nézünk a világegyetemben, sehol sem látunk Kardasov-3-as (K3) civilizációt: a megfigyelhető világegyetemben lévő ezermilliárd $\left(10^{12}\right)$ galaxis közül az infravörös tartományban legjobban látható százezer $\left(10^{5}\right)$ egyikében sem. ${ }^{11} 80$ fényéves körzetben nem találtunk egyetlen K2-es civilizációt sem, pedig alaposan megvizsgáltunk több száz csillagot, és ha 3000 fényéven belül lenne egy, valószínüleg azt is észrevennénk. ${ }^{12} \mathrm{Nem}$ látjuk nyomát semmilyen mesterséges beavatkozásnak a Naprendszerben; nincsenek földönkívüliek a Földön, és annak sincs semmi nyoma, hogy valaha lettek volna. (Az pedig már csak hab a tortán, hogy eddig nem fogtunk semmilyen üzenetet sem, de ez csodaszámba is menne, tekintve, hogy az elektromágneses spektrumnak milyen kicsi hányadát figyeljük és mennyire rövid ideje.) Ezzel szemben viszont nagyon is jól sikerül leírni bolygónk, naprendszerünk, a szomszédos csillagrendszerek, a Tejút, de még a többi galaxis müködését is egyszerü természeti törvényekkel, anélkül, hogy bármilyen szándékosságot kellene feltételeznünk. Azok a természeti törvények, amelyek működnek az egyik bolygó (csillag, galaxis) esetében, működnek az összes többi esetében is, nem látunk semmit, ami kilógna a sorból. ${ }^{13}$ Amiből az következik, hogy a földönkívüliek vagy mindenütt

\footnotetext{
8 Nikolai S. Kardashev: Transmission of information by extraterrestrial civilisations. Soviet Astronomy, 8. (1964), 2. 219. A skálát később Carl Sagan módosította úgy, hogy meghatározta az egyes szintek közötti lépcsőket, így lehetővé téve tört értékek elérését is: az emberiség jelenleg a 0,73-as szinten áll.

9 Milan M. Ćirković: Kardashev's classification at 50+: A fine vehicle with room for improvement. Serbian Astronomical Journal, (2015), 191. 11.

10 Jason T. Wright - R. L. Griffith - S. Sigurdsson et alii: The G infrared search for extraterrestrial civilisations with large energy supplies: II. Framework, strategy, and first result. The Astrophysical Journal, 792. (2014b), 1. 4-5.

11 Roger L. Griffith et alii: The $\hat{G}$ infrared search for extraterrestrial civilisations with large energy supplies: III. The reddest extended sources in WISE. The Astrophysical Journal Supplement Series, 217. (2015), 2. 32.

12 Jason Wright - T. B. Mullan - S. Sigurdsson - M. S. Povich: The G infrared search for extraterrestrial civilisations with large energy supplies: I. Background and justification. The Astrophysical Journal, 792. (2014a), 1. 13-14.

13 Robin Hanson: The great filter - Are we almost past it?. [online], 1998. 09. 15. Forrás: gmu.edu [2021. 04. 15.]
} 
ott vannak, ${ }^{14}$ vagy sehol sincsenek - márpedig azt biztosan tudjuk, hogy itt nincsenek. Nemcsak a Naprendszerben, de a környékén sem.

A fent leírt ellentétet - vagyis az ellentmondást a között, hogy nem érzékeljük a földönkívüliek létezését és a között, hogy a világegyetemről meglévő ismereteink alapján nagyon is kellene - Enrico Fermi után Fermi-paradoxonnak nevezzük. Ennek a cikknek nem célja számba venni az elmúlt 70 évben százszámra javasolt valamennyi megoldást, ${ }^{15}$ megelégszik azzal, hogy azokat négy nagyobb kategóriába rendezze: 1. földönkívüli intelligens civilizációk nem léteznek; 2. léteznek ugyan, de nem fognak hozzá a gyarmatosításhoz; 3. megkezdték a gyarmatosítást, de még nem érték el a Naprendszert; 4. a Naprendszer is része a galaktikus birodalomnak. Az első különösebb magyarázatot nem igényel (hacsak annyit nem, hogy sokkal kisebb az intelligens élet kialakulásának az esélye, mint általában gondoljuk), a másik hármat azonban érdemes alaposabban megvizsgálni.

A második kategóriába (nem indulnak el) tartozik a transzcendencia forgatókönyve, amely szerint a fejlett civilizációk maguk mögött hagyják a fizikai valóságot és virtuális világba, számítógép-generálta szimulációba költöznek. Egy ilyen civilizációnak nem lenne szükségszerüen nagy az energiafelhasználása (nem kellene elérnie a K2 szintet), ezért jelenlegi eszközeinkkel nem vennénk észre, még ha viszonylag közel lenne is. Az is joggal feltételezhető, hogy ha egy faj egyszer már átlép a virtuális valóságba, többé nincs oka viszszatérni a fizikai világba. Csakhogy a virtuális élet nem zárja ki a fizikai univerzum gyarmatosítását, sőt, utóbbi éppenséggel logikus akár a túlélés, akár az erőforrások maximalizálása érdekében. Másrészt ez a forgatókönyv nem magyarázza, hogy miért zárkózik törvényszerűen minden idegen civilizáció a virtuális létbe - márpedig elég százból akár egyetlen egy is, amelyik nem így tesz, máris az eredeti paradoxonnál tartunk. ${ }^{16}$ Azt persze nem lehet kizárni, hogy - az egész megfigyelhető univerzumban, nem csak a galaxisban - van néhány (egy kézen megszámolható) civilizáció, amely anélkül, hogy ennek valamilyen közös oka lenne, egymástól függetlenül ezt az utat választotta.

A harmadik kategória (még nem értek ide) különbözik a többitől abban, hogy nem egy egyensúlyi állapotot ír le (már itt vannak, illetve nem is jönnek), hanem egy időlegeset. Ez az az elképzelés, amely magában hordozza annak a lehetőségét, hogy bár eddig még nem találkoztunk idegenekkel, lehetséges, hogy belátható időn belül, akár életünk során fogunk; ennélfogva a téma szórakoztató célú feldolgozásai jellemzően erre épülnek. Az egyik lehetséges magyarázata az lenne, ha annak ellenére, hogy a galaxis Föld-típusú bolygóinak jelentékeny hányada idősebb a miénknél, lenne valamilyen közös, általánosan érvényes oka annak, hogy miért csak a közelmúltban alakulhatott ki rajtuk intelligens élet. Ha ez így lenne, az azt jelentené, hogy még csak nemrég indult meg a verseny a galaxis kolonizálásáért. Ennek a bizonyos feltételezett gátló tényezőnek, ami az intelligens élet kialakulását akadályozta, alig néhány millió éve kellett volna megszünnie - és nemcsak

14 Van például olyan elgondolás, amely szerint minden aktív galaxismag valójában egy hatalmas mesterséges erőmű, de ez könnyen cáfolható. Wright et alii (2014b) i. m. 5.

15 Lásd például Milan M. Ćirković: The great silence: Science and philosophy of Fermi's paradox. Oxford University Press, 2018 vagy Stephen Webb: If the universe is teeming with aliens ... Where is everybody?: Seventy-five solutions to the Fermi paradox and the problem of extraterrestrial life. Springer, 2015.

16 Michael H. Hart: An explanation for the absence of extraterrestrials on Earth. Quarterly Journal of the Royal Astronomical Society, 16. (1975), 132. 
a Tejútban, hanem a szomszédos Andromédában és Triangulumban is, és minden más olyan galaxisban, amit viszonylag jól meg tudunk figyelni. Hogy mi lenne ez a tényező, azt eddig nem sikerült meggyőzően bemutatni, mindenesetre valami olyasminek kellene lennie, ami nemcsak a galaxisra, hanem az egész világegyetemre érvényes.

Egy másik lehetőség, hogy a gyarmatosítás sokkal lassabban halad, mint fent feltételeztük. Ha a Neumann-szondák sebessége nem a fénysebesség öt százaléka vagy öt ezreléke, hanem csak egy tízezrede (ez a jelenlegi ürszondák sebességének nagyságrendje), a Tejút gyarmatosítása egymilliárd évig tarthat. Elképzelhető, hogy létezik egy az emberiség előtt ma még ismeretlen, megkerülhetetlen törvényszerűség, ami jelentősen korlátozza a növekedés ütemét, ${ }^{17}$ de az is lehet, hogy a terjeszkedő civilizáció tudatosan korlátozza azt, hogy hosszabb távon maradjon fenntartható. Csakhogy erös ösztönzők szólnak amellett, hogy ne tegyen így. Egy hódító civilizáció joggal feltételezné, hogy nem ő az egyetlen, ami a minél gyorsabb terjeszkedés mellett szól, hiszen könnyebb egy üres bolygórendszert elfoglalni, mint egy olyat, amit valaki védelmez. Ha több versengő hódító birodalmat feltételezünk, akkor minden egyes újabb gyarmat elfoglalása nemcsak a birodalom erőforrásait növeli, de egyúttal a másikat is megfosztja ugyanezektöl az erőforrásoktól - ezt a logikát jól ismerjük az emberiség történelméből. A terjeszkedés ütemének maximalizálása kitolja a más civilizációkkal való találkozás időpontját és távolságát is. ${ }^{18}$ Még ha egy faj korlátozná is szándékosan a saját növekedését, miért tett volna így minden egyes faj történelme során mindvégig?

Az azonban nagyon is lehetséges, hogy bár a Tejútban és a környező galaxisokban nincs K3-as civilizáció, jóval távolabb, néhány milliárd fényévnyire viszont van. Ekkor a Fermiparadoxon nem is áll fenn: még nem kellett volna ideérniük, hiszen ekkora távolság megtételéhez több tízmilliárd évre - akár a világegyetem korát is meghaladó időtartamra - lenne szükség, de abban sincsen ellentmondás, hogy nem látjuk őket, hiszen ezeknek a galaxisoknak nem a jelenlegi, csak a milliárd évekkel ezelötti állapotát tudjuk megfigyelni. Vagyis csak annyit látunk, hogy egymilliárd évvel ezelőtt, amikor a fény elindult onnan a Föld felé, nem volt semmi különleges az adott galaxisban, nem azt, hogy most van-e.

A negyedik kategóriába tartozó magyarázatok szerint bár a galaxis (és talán a Naprendszer) kolonizálása megtörtént, ezt valamiért nem érzékeljük. Könnyen leszámolhatunk azzal az ötlettel, hogy ez azért lenne így, mert a gyarmatosítás elhaladt mellettünk és a Naprendszer és környéke (e feltételezés szerint több ezer fényév sugarú környéke) valamiért kimaradt belőle. Igaz, hogy egy ilyen fent leírt, bolygórendszerről bolygórendszerre lépegető gyarmatosítás során a Neumann-szondák meghibásodásából fakadóan óhatatlanul kialakulnának kisebb vagy nagyobb buborékok, de vajon nem törekedne-e a gyarmatosító arra, hogy betömje ezeket a réseket? Nem lenne-e valamilyen felügyeleti mechanizmus beépítve a szondákba, amely ellenőrzi, hogy a szomszédos rendszerbe küldött testvérük elvégezte-e a feladatát? Egy 85 ezer fényév sugarú galaxisban több ezer fényév sugarú lyukakat kihagyni egyáltalán nem elhanyagolható léptékủ hiba.

\footnotetext{
Almár Iván: Analogies between Olbers' Paradox and the Fermi Paradox. Acta Astronautica, 26. (1992), 3-4. 255.

18 Robin Hanson et alii: If loud aliens explain human earliness, quiet aliens are also rare. [online], 2021. 03. 26. 21. Forrás: arxiv.org [2021. 04. 15.]
} 
Egy lényegét tekintve hasonló elképzelés szerint a gyarmatosítók már tovahaladtak és hátrahagyták a Naprendszert, amit már kizsigereltek annyira, amennyire akartak. Ennek az elgondolásnak, akárcsak az elözőnek, az a fö gyengéje, hogy bár arra megkísérel magyarázatot adni, hogy miért nincs jelenleg földönkívüli civilizáció a környezetünkben, arra nem, hogy miért nem látjuk annak sem nyomát, hogy valaha lett volna. Ráadásul attól, hogy itt nincsenek, a távolban még ugyanúgy érzékelnünk kellene őket. Hacsak ki nem haltak. De mi lehetett az a kataklizma, ami kipusztított egy galaxisszerte elterjedt fajt, de közben a Földön semmilyen nyomot nem hagyott? És hogyan hatott ugyanez az öszszes többi galaxisban is? Hol vannak ennek a civilizációnak a romjai? Könnyen belátható, hogy sem a „továbbmentek”, sem a „kihaltak” forgatókönyv nem megoldása a Fermiparadoxonnak. Ahogyan az az elgondolás sem ad rá magyarázatot, hogy azért nem érzékeljük az idegeneket, mert olyan technológiát használnak, ami számunkra láthatatlan. Bár elvben nem zárható ki, hogy létezik olyan energiaforrás - mondjuk a sötét energia megcsapolása ${ }^{19}$-, amely annyival hatékonyabb a csillagok energiájának hasznosításánál, hogy minden ürutazó civilizáció egyöntetủen, egymástól függetlenül átáll ennek a használatára (mint ahogy mi sem építünk mechanikus számítógépeket, amióta van elektronikus), a tevékenységük semmilyen egyéb nyomát sem észleljük.

Az a - szintén ebbe a kategóriába tartozó - feltételezés sem tartható, hogy az idegenek rejtőzködnek előlünk. Bár ezt technológiai fölényük birtokában kétségkívül megtehetnék, ez azt jelentené, hogy minden egyes idegen civilizáció egyaránt rejtőzködik. Ez csak akkor lehetséges, ha vagy csak néhány ilyen civilizáció van, vagy van egy, amely ezt a többitől is kikényszeríti. Ez utóbbi elképzelésnek egy különösen lehangoló alesete az a forgatókönyv, hogy van egy galaktikus birodalom, amely minden más fajt megsemmisít. ${ }^{20}$ Lehet, hogy szondái már évmilliókkal ezelőtt szétrajzottak a galaxisban és minden bolygórendszerben figyelik, hogy kialakul-e intelligens élet, és ha igen, elpusztítják azt. Lehet, hogy nem gazdaságos minden életformát azonnal kiirtani, talán mert a legtöbb magától is kipusztul, de egy ponton túl a galaktikus birodalom beavatkozik (még azelött, hogy egy ürutazó civilizáció útjára indítaná a maga Neumann-szondáját), megakadályozandó, hogy kialakulhasson egy vetélytárs. De annak az esélye, hogy a birodalom szondái éppen az elmúlt 5000 évben érkeztek, amikor az ember már kémlelte az égboltot, elhanyagolhatóan csekély. Öt- vagy kétszázmillió évvel ezelőtt, amikor a Naprendszerbe érkeztek, mi elől rejtőztek volna el? És egyáltalán, miért rejtőzködnének most? Könnyebb-e egy technológiailag felsőbbrendű civilizációnak kiirtania minket, ha rejtőzködik, mint ha nem?

Végül, vannak azok az elméletek, amelyek az eddig felsorolt kategóriák egyikébe sem sorolhatók be, mert valamilyen metafizikai magyarázatot feltételeznek - például hogy a világ nem valóságos, hanem egy számítógépes szimuláció ${ }^{21}$-, és amelyekben ennélfogva közös, hogy nem falszifikálhatók. (Szintén nem foglalkoztunk a fénysebesség esetleges meghaladhatóságával, de annyit érdemes megjegyezni, hogy az csak megerősítené a paradoxont és kizárná a „nem értek ide” kategóriába tartozó magyarázatokat.)

19 Wright et alii (2014b) i. m. 6.

20 Glen David Brin: The 'Great Silence': The controversy concerning extraterrestrial intelligent life. Quarterly Journal of the Royal Astronomical Society, 24. (1983), 3. 296.

21 Lásd például Nick Bostrom: Are you living in a computer simulation? Philosophical Quarterly, 53. (2003), 211. $243-255$. 


\section{Kell-e készülnünk a találkozásra?}

A Fermi által megfogalmazott probléma alighanem a tudomány egyik legfontosabb és legizgalmasabb kérdése, aminek tanulmányozása - jelentőségét figyelembe véve - önmagában is hasznos. De joggal vetődik fel a kérdés: mit jelent ez számunkra, az emberiség számára? Milyen cselekvési utak következnek a fenti eszmefuttatásból?

Látszólag kibékíthetetlen ellentét feszül a között a két tény között, hogy ha a világegyetemben lennének intelligens földönkívüli lények, akkor érzékelnünk kellene a jelenlétüket, és a között, hogy semmi erre utalót nem látunk. Olyannyira, hogy számos alternatíva áttekintése után mindössze két olyan lehetőséget találtunk, amelyek úgy adnak erre magyarázatot, hogy belső ellentmondásoktól mentesek. Mielőtt ezeket külön-külön megvizsgáljuk, szögezzük le: ha felmerül annak a lehetősége, hogy az emberiség érintkezésbe lép egy földönkívüli intelligens fajjal, túlélésünk érdekében nem a feltételezett szándékaikból, hanem az ők és a saját magunk képességeiből kell kiindulnunk. És jegyezzük meg azt is, hogy bár ezek a magyarázatok a többinél kétségkívül meggyőzőbbnek mutatkoznak, akkor, amikor erre a kettőre szükítjük a további gondolkodást, nem bizonyosságról, csupán feltételezésről van szó: arra hagyatkozunk, amit tudunk, mert nem tehetünk mást, de közben mindvégig emlékeztetnünk kell magunkat arra is, hogy ez a tudás ma még sokkal kevesebb annál, mint ami a magabiztossághoz elegendő lenne.

A két lehetőség egyike tehát az, hogy földönkívüli civilizációk vagy egyáltalán nem léteznek, vagy léteznek ugyan, de ilyen vagy olyan okból egyikük sem hódította meg a galaxisát, legfeljebb néhány bolygórendszerre terjednek ki. Mivel ezek a civilizációk egymástól függetlenül, nem pedig egy közös ok következtében választották a bezárkózás útját, legfeljebb néhány lehet belőlük (mert ha sok lenne, közülük legalább néhány másképpen döntött volna). Azt is tudjuk, hogy történelmük során mindvégig bezárkózóak voltak (mert ha akár egyszer is útra indultak volna, létrejönne a paradoxon), és mivel ez már évmilliók óta így van, azt feltételezhetjük, hogy a bezárkózás valamiért egyirányú folyamat, amiből viszont az az egyetlen következtetés adódik, hogy ezután sem fognak elindulni. Mindezekből pedig az következik, hogy ha a biztonságunk szempontjából tekintjük, semmi dolgunk nincs velük.

A másik lehetőség, hogy vannak ugyan - akár több galaxist is magukban foglaló, terjeszkedő - szupercivilizációk, de olyan messze (több milliárd fényévnyire), hogy még az azelötti állapotukat látjuk, hogy létrejöttek volna. Ebben az esetben az a kérdés, hogy ha észlelnénk, hogy közelednek, lenne-e elég időnk reagálni rá, illetve hogy mi történne, amikor ideérnek. Először is, egyáltalán nem magától értetődő, hogy érdemes a galaxison túlra is terjeszkedni: a Tejút kolonizálásának időtávja 4,4 millió év, ha azzal számolunk, hogy a szondák a fénysebesség huszadával haladnak (illetve 33 millió, ha tizedekkora sebességgel) és az emberiség rendelkezésére álló energiaforrások megszázmilliárdszorozódását eredményezné (mert ennyi csillag van a galaxisban). Ehhez képest a legközelebbi nagy galaxis, a két és fél millió fényévre lévő Androméda elérése 50 millió (illetve 500 millió) évbe telne, és legfeljebb csak megtízszerezné az erőforrásokat. Ráadásul az sem egyértelmü, hogy ezek kinek az erőforrásai lennének: milyen értelemben lehetne ezt egységes birodalomként vagy civilizációként értelmezni, ha a két pontja közötti üzenetváltás ötmillió 
évbe telik? Akarna-e egy intelligens faj olyan kolóniát alapítani, amelynek a működésébe semmilyen beleszólása sincs?

Talán azért, hogy másokat megakadályozzon ebben. Bár minden űrutazó civilizáció juthat arra a következtetésre, hogy a világegyetem gyarmatosítása nem éri meg, eközben elfogadhatja azt is, hogy ha annak erőforrásait átengedi másoknak, az potenciálisan fenyegetést jelenthet számára. Azt is feltételezheti, hogy mások is ugyanígy gondolkodnak, ezért - különösen, ha ennek költsége alacsony - igyekezhet megelözni ezeket a másokat, még akkor is, ha semmi nem utal a létezésükre. ${ }^{22} \mathrm{Ha}$ az Androméda-galaxisban bármilyen mesterséges tevékenységet észlelnénk, még akkor is több százezer évünk lenne felkészülni a találkozásra, ha a földönkívüli ürhajók a fénysebesség 90 százalékával közelítenék meg a Tejutat. Egy intergalaktikus háborúban a védekező fél behozhatatlan anyagi fölényben van, mert a galaxis összes energiája és egész anyaga a rendelkezésére áll, miközben a támadónak többmillió fényéves sivatagon kell átkelnie.

Akár az egyik, akár a másik magyarázatot fogadjuk el a Fermi-paradoxonra, egyik sem teszi szükségessé, hogy nekivágjunk a világür gyarmatosításának. Van mégis egy jó okunk arra, hogy más bolygókon, majd más csillagrendszerekben is megvessük a lábunkat: a Föld sérülékenysége. Ez nemcsak az olyan, potenciálisan az emberiség kipusztulásával fenyegető, de rendkívül alacsony valószínűségű természeti katasztrófákkal szemben nyújtana védelmet, mint a gamma-kitörések és a szupernóvák, de attól is megvédene bennünket, hogy saját magunkat pusztítsuk ki.

\section{Felhasznált irodalom}

Almár Iván: Analogies between Olbers' Paradox and the Fermi Paradox. Acta Astronautica, 26. (1992), 3-4. 253-256. Online: https://doi.org/10.1016/0094-5765(92)90107-T

Armstrong, Stuart - Anders Sandberg: Eternity in six hours: Intergalactic spreading of intelligent life and sharpening the Fermi Paradox. Acta Astronautica, 89. (2013), 1-13. Online: https://doi.org/10.1016/j. actaastro.2013.04.002

Bostrom, Nick: Are you living in a computer simulation? Philosophical Quarterly, 53. (2003), 211. 243-255. Online: https://doi.org/10.1111/1467-9213.00309

Brin, Glen David: The 'Great Silence': The controversy concerning extraterrestrial intelligent life. Quarterly Journal of the Royal Astronomical Society, 24. (1983), 3. 283-309.

Ćirković, Milan M.: Fermi's paradox: The last challenge for copernicanism? Serbian Astronomical Journal, (2009), 178. 1-20. Online: https://doi.org/10.2298/SAJ0978001C

Ćirković, Milan M.: Kardashev's classification at 50+: A fine vehicle with room for improvement. Serbian Astronomical Journal, (2015), 191. 1-15. Online: https://doi.org/10.2298/SAJ1591001C

Ćirković, Milan M.: The great silence: Science and philosophy of Fermi's paradox. Oxford University Press, 2018.

Griffith, Roger L. - Jason T. Wright - Jessica Maldonado et alii: The G infrared search for extraterrestrial civilisations with large energy supplies: III. The reddest extended sources in WISE. The Astrophysical Journal Supplement Series, 217. (2015), 2. 1-34. Online: https://doi.org/10.1088/0067-0049/217/2/25

Hanson, Robin: The Great Filter - Are We Almost Past It?. [online], 1998. szeptember 15., Forrás: gmu.edu [2021. 04. 15.]

Hanson, Robin - Daniel Martin - Calvin McCarter - Jonathan Paulson: If loud aliens explain human earliness, quiet aliens are also rare. [online], 2021. 03. 26. Forrás: arxiv.org [2021. 04. 15.]

22 Stuart Armstrong - Anders Sandberg: Eternity in six hours: Intergalactic spreading of intelligent life and sharpening the Fermi Paradox. Acta Astronautica, 89. (2013), 1-13. 
Hart, Michael H.: An explanation for the absence of extraterrestrials on Earth. Quarterly Journal of the Royal Astronomical Society, 16. (1975), 128-135.

Kardashev, Nikolai S.: Transmission of information by extraterrestrial civilisations. Soviet Astronomy, 8. (1964), 2. 217-221.

Neumann, John von: Theory of Self-reproducing Automata. Urbana-London, University of Illinois Press, 1966.

Tipler, Frank J.: Extraterrestrial intelligent beings do not exist. Quarterly Journal of the Royal Astronomical Society, 21. (1980), 267-281. Online: https://doi.org/10.1063/1.2914542

Webb, Stephen: If the universe is teeming with aliens ... Where is everybody?: Seventy-five solutions to the Fermi paradox and the problem of extraterrestrial life. Springer, 2015.

Wright, Jason - T. B. Mullan - S. Sigurdsson - M. S. Povich: The G infrared search for extraterrestrial civilisations with large energy supplies: I. Background and justification. The Astrophysical Journal, 792. (2014a), 1. 1-16. Online: https://doi.org/10.1088/0004-637X/792/1/26

Wright, Jason T. - R. L. Griffith - S. Sigurdsson et alii: The G infrared search for extraterrestrial civilisations with large energy supplies: II. Framework, strategy, and first result. The Astrophysical Journal, 792. (2014b), 1. 1-12. Online: https://doi.org/10.1088/0004-637X/792/1/27 